Www.jmscr.igmpublication.org

Impact Factor (SJIF): 6.379

Index Copernicus Value: 79.54

ISSN (e)-2347-176x ISSN (p) 2455-0450

crossrefDOI: https://dx.doi.org/10.18535/jmscr/v6i11.44

Journal Of Medical Science And Clinical Research

\title{
Level of C-Reactive Protein in Prognosis of Unstable Angina and Non St Elevation Myocardial Infarction
}

\author{
Authors \\ Dr P.K. Agrawal ${ }^{1}$, Dr Atul Kumar², Dr Md Tabrez Alam³, Dr Usman Rasool ${ }^{3}$ \\ Dr Raghib Hasan ${ }^{3}$, Dr Farogh Haidry ${ }^{3}$, Dr Rakesh Raushan ${ }^{3}$ \\ ${ }^{1}$ Professor and Head, ${ }^{2}$ Professor, ${ }^{3}$ Post Graduate Trainee \\ Department of General Medicine, KMCH Katihar, India
}

\begin{abstract}
Introduction: Acute coronary syndrome (ACS) is defined as a sudden and rapid compromise of coronary blood flow usually because of rupture of an atherosclerotic lesion and subsequent thrombus formation in the coronary artery. It includes ST Elevated MI, UNSTABLE ANGINE and NON-ST Elevation MI.

$C$ Reactive Protin is an acute phase protein produced mainly by the liver in response to intereukin 6, is a marker of inflammatory processes that contribute importantly to atherogenesis, plaque disruption and thrombosis.

Aims And Objectives

1) To find out the number of the patients with acute coronary syndrome (unstable angina and non ST elevation MI) that have raised C-reactive protein.

2) Whether there is any correlation between the severity of acute coronary syndrome and the quantitative and qualitative estimation of $C$-reactive protein.

3) To assess whether level of $C$-reactive protein bears a positive correlation with the level of cardiac enzymes.

4) To assess whether the C-reactive protein could be considered as one of the factors for risk stratification of acute coronary syndrome

Materials and Method: 60 patients of acute coronary syndrome (unstable angina and non-ST elevation MI) admitted in Intensive Coronary Care Unit (ICCU) of Katihar Medical College \& Hospital along with 30 age and sex matched healthy person as control were formed the material of the study.

Type of Study: Descriptive Study

Inclusion Criteria

1) Adult patients of both sexes

2) Informed and a written consent

3) The patient may be either a known case of ischaemic heart disease or the present attack of unstable angina may be the first manifestation of the disease.

\section{Exclusion Criteria}

1) ST-Elevated Myocardial infarction

2) Any infective or inflammatory and neoplastic condition that is known to be associated with an acute phase response thereby causing a rise in $(C R P) C$-reactive protein.
\end{abstract}


3) post-infarct angina patients.

Duration of Study: December 2016 to May 2018

Results: At Ohr., $20 \%$ of patients had negative C-reactive protein (CRP) levels while $80 \%$ of the population had positive $C$-reactive protein (CRP) levels. This was equally distributed over the 3 frequency distribution ((viz. $6<12,12-<24$ and $24-48)$. Those who had initial negative $C$-reactive protein (CRP) values remained so throughout 24 hrs following admission. At 6hrs, 23.33\% had CRP values between $6-<12$, $30 \%$ had C-reactive protein (CRP) $12-<24$ while, $26.67 \%$ had values > $24 \mathrm{gm} / \mathrm{L}$. At $24 \mathrm{hr}, 36.67 \%$ had values between $6-<12$, while $16.66 \%$ of population still had very high $(>24 \mathrm{gm} / \mathrm{L}) \mathrm{C}$-reactive protein $(C R P)$ levels.

The incidence of risk factors in the study group shows diabetes mellitus was present in 26 patients (43.33\%). Thirty-two patients (53.33\%) gave history of smoking. Forty patients (66.67\%) were hypertensive and 24 patients (40\%) were dyslipidaemics. Past history of IHD was present in 26 patients (43.33\%). Hypertension was detected to be present in majority of the patients (Table-2).

Conclusion: The present study has shown a positive correlationship between raised $C$-reactive protein $(C R P)$, high incidence of MACE and poor outcome both immediate and 1 year and 6 months follow up. There is high incidence in diabetcis and smokers and hypertensives.

\section{Introduction}

Acute coronary syndrome (ACS) is defined as a sudden and rapid compromise of coronary blood flow usually because of rupture of an atherosclerotic lesion and subsequent thrombus formation in the coronary artery. It includes ST Elevation MI, UNSTABLE ANGINE and NONST Elevation MI.

C Reactive Protin is an acute phase protein produced mainly by the liver in response to intereukin 6 , is a marker of inflammatory processes that contribute importantly to atherogenesis ,plaque disruption and thrombosis.

\section{Aims and Objectives}

1) To find out the number of the patients with acute coronary syndrome (unstable angina and non ST elevation MI) that have raised C-reactive protein.

2) Whether there is any correlation between the severity of acute coronary syndrome and the quantitative and qualitative estimation of C-reactive protein.

3) To assess whether level of C-reactive protein bears a positive correlation with the level of cardiac enzymes.

4) To assess whether the C-reactive protein could be considered as one of the factors for risk stratification of acute coronary syndrome

\section{Materials and Method}

60 patients of acute coronary syndrome (unstable angina and non-ST elevation MI) admitted in Intensive Coronary Care Unit (ICCU) of Katihar Medical College \& Hospital along with 30 age and sex matched healthy person as control were formed the material of the study.

Type of Study: Descriptive Study

\section{Inclusion Criteria}

1) Adult patients of both sexes

2) Informed and a written consent

3) The patient may be either a known case of ischaemic heart disease or the present attack of unstable angina may be the first manifestation of the disease.

\section{Exclusion Criteria}

1) ST -Elevated Myocardial infarction

2) Any infective or inflammatory and neoplastic condition that is known to be associated with an acute phase response thereby causing a rise in (CRP) C-reactive protein.

3) Post-infarct angina patients.

Duration of Study: December 2016 to May 2018 


\section{Observation}

Distribution of C-reactive protein in the study population

\begin{tabular}{|l|c|c|c|c|}
\hline $\begin{array}{l}\text { CRP values } \\
(\mathbf{g m} / \mathbf{L})\end{array}$ & $\begin{array}{c}\text { At 0 hr } \\
\text { No of patients }\end{array}$ & $\begin{array}{c}\text { AT 6 hr } \\
\text { No of patients }\end{array}$ & $\begin{array}{c}\text { At 12 hr } \\
\text { No of patients }\end{array}$ & $\begin{array}{c}\text { At 24 hr } \\
\text { No of patients }\end{array}$ \\
\hline$<6$ & $12(20 \%)$ & $12(20 \%)$ & $12(20 \%)$ & $12(20 \%)$ \\
\hline $6-<12$ & $16(26.67 \%)$ & $14(23.33 \%)$ & $18(30 \%)$ & $22(36.67 \%)$ \\
\hline $12-<24$ & $16(26.67 \%)$ & $18(30 \%)$ & $18(30 \%)$ & $16(26.67 \%)$ \\
\hline $24-48$ & $16(26.66 \%)$ & $16(26.67 \%)$ & $12(20 \%)$ & $10(16.66 \%)$ \\
\hline
\end{tabular}

At $0 \mathrm{hr}$., $20 \%$ of patients had negative C-reactive protein (CRP) levels while $80 \%$ of the population had positive C-reactive protein (CRP) levels. This was equally distributed over the 3 frequency distribution ((viz. 6<12, $12-<24$ and $24-48$ ). Those who had initial negative $\mathrm{C}$-reactive protein (CRP) values remained so throughout $24 \mathrm{hrs}$ following admission. At 6hrs, $23.33 \%$ had CRP values between $6-<12$, 30\% had C-reactive protein (CRP) $12-<24$ while, $26.67 \%$ had values $>24 \mathrm{gm} / \mathrm{L}$. At $24 \mathrm{hr}, 36.67 \%$ had values between
$6-<12$, while $16.66 \%$ of population still had very high $(>24 \mathrm{gm} / \mathrm{L}) \mathrm{C}$-reactive protein (CRP) levels. The incidence of risk factors in the study group shows diabetes mellitus was present in 26 patients (43.33\%). Thirty-two patients $(53.33 \%)$ gave history of smoking. Forty patients $(66.67 \%)$ were hypertensive and 24 patients (40\%) were dyslipidaemics. Past history of IHD was present in 26 patients $(43.33 \%)$. Hypertension was detected to be present in majority of the patients (Table-2).

\section{Comparison of CRP level among diabetics and non-diabetics in the study population}

\begin{tabular}{|l|c|c|c|c|}
\hline & No. of patients & $\begin{array}{c}\text { Mean CRP values } \pm \\
\text { SD }(\mathbf{g m} / \mathbf{L})\end{array}$ & t- values & p - values \\
\hline Diabetics & 26 & $14.40 \pm 8.36$ & \multirow{2}{*}{1.30} & $\mathrm{p}<0.1$ (NS) \\
\hline Non-diabetics & 34 & $10.72 \pm 6.65$ & & \\
\cline { 1 - 3 }
\end{tabular}

The mean C-reactive protein (CRP) level among the thirteen diabetic patients in our study was $14.40 \pm 8.36 \mathrm{gm} / \mathrm{L}$ and the mean C-reactive protein (CRP) level among seventeen non-diabetic patients was $10.72 \pm 6.65 \mathrm{gm} / \mathrm{L}$. Although the overall mean C-reactive protein (CRP) level was found to be higher in diabetics than non-diabetics in our study, this difference was not statistically significant. $(\mathrm{p}<0.1)$.

\section{Comparison of CRP level among smoker and non-smoker in the study population:-}

\begin{tabular}{|l|c|c|c|c|}
\hline & No. of patients & $\begin{array}{c}\text { Mean CRP values } \pm \\
\text { SD }(\mathbf{g m} / \mathbf{L})\end{array}$ & t - values & p - values \\
\hline Smoker & 32 & $13.76 \pm 9.46$ & \multirow{2}{*}{1.08} & $\mathrm{p}<0.1$ (NS) \\
\hline Non-smoker & 28 & $10.66 \pm 5.98$ & & \\
\hline
\end{tabular}

The mean CRP level among the sixteen smoker patients in our study was $13.76 \pm 9.46 \mathrm{gm} / \mathrm{L}$ and that of non-smoker was $10.66 \pm 5.98 \mathrm{gm} / \mathrm{L}$. (CRP) level was found to be higher among smoker in our study, this difference was not statistically significant $(\mathrm{p}<0.1)$.

Although the overall mean C-reactive protein

Comparison of CRP level among hypertensive and normotensive patients in the study group :

\begin{tabular}{|l|c|c|c|c|}
\hline & No. of patients & $\begin{array}{c}\text { Mean CRP values } \pm \\
\text { SD }(\mathbf{g m} / \mathbf{L})\end{array}$ & $\mathbf{t}$ - values & p- values \\
\hline Hypertensives & 40 & $12.19 \pm 6.94$ & 0.116 & $\mathrm{p}<0.1$ (NS) \\
\hline Normotensives & 20 & $12.56 \pm 8.78$ & 0.16 \\
\hline
\end{tabular}

Mean C-reactive protein (CRP) level among the twenty hypertensives patients in our study was $12.19 \pm 6.94 \mathrm{gm} / \mathrm{L}$ and that of normotensives was $12.56 \pm 8.78 \mathrm{gm} / \mathrm{L}$. In our study, normotensives had a mean C-reactive protein (CRP) level more than the hypertensives but this small difference was not statistically significant $(\mathrm{p}<0.1)$. 


\section{Discussion}

As regards, incidence of traditional cardiovascular risk factors in the study population, hypertension was found to be the commonest $(66.67 \%)$ followed by smoking (53.33\%) and diabetes and past history of ischaemic heart disease sharing the $3^{\text {rd }}$ position with $43.33 \%$ each Dyslipidaemia was the C-reactive protein least common (40\%) risk factor detected .

The mean value of CRP in the study population was significantly higher than that of control. (Table - 11) Higher CRP values are also reported both in ACS and IHD by number of authors like Berk BC et $\mathrm{al}^{8}$, Liuzzo $\mathrm{G}$ et $\mathrm{al}^{10}$, Bhagat $\mathrm{S}$ et $\mathrm{al}^{100}$ etc. Study of C-reactive protein in patients with acute myocardial infarction attending tertiary care teaching hospital in Saurashtra region of Gujarat, India Shripad R. Kausadikar1*, Hina A. Mehra2, Krishnakant P. Pathak shows that correlates the duration of chest pain, i.e., the time interval during which chest pain (cardinal symptom) lasted in the patients having acute myocardial infarction. It is evident from above that the maximum rise of CRP levels took place when the chest pain lasted for more than 6 hours, being $90 \%$ of the times raised between 6-12 hours and $100 \%$ of the times when the pain lasted for more than 12 hours. The $\mathrm{p}$ value was found to be $<0.05$ which is statistically significant.

Further continuing with subgroup analysis of Creactive protein (CRP) among diabetics and nondiabetics in the study population, the difference in C-reactive protein (CRP) values between the two groups was not found to be statistically significant (Table-13). Similar statistically non-significant differences were seen between smokers and nonsmokers (Table- 14) and between hypertensives and non-hypertensives (Table-15). This is in contrast to Pearson TA et $\mathrm{al}^{77}$, Haverkate $\mathrm{F}$ et al where a statistically significant positive correlation were established between C-reactive protein (CRP) and hypertension, smoking and diabetes. In the present study too there was trend of higher C-reactive protein (CRP) in hypertensives, smoker and diabetics, but it was not statistically significant because of small sample size.

C-reactive protein (CRP) levels in dyslipidaemics in the present study group however was higher than subjects with normal lipids and this difference was statistically significant at ' $p$ ' value of <0.001 (Table- 16). This again is in confirmation with Haverkate $\mathrm{F}$ et al.

\section{Summary}

The present study consists of 60 patients of acute coronary syndrome (unstable angina and non ST elevation myocardial infarction) and 30 age-sex matched healthy control.:- The present study has shown a positive correlationship between raised C-reactive protein (CRP), high incidence of MACE and poor outcome both immediate and 1 year and 6 months follow up. There is high incidence in diabetics and smokers and hypertensives.

Hypertension was found to be the commonest risk factor followed by smoking, diabetes and dyslipidaemia.

\section{Conclusion}

The present study has shown a positive correlationship between raised $\mathrm{C}$-reactive protein (CRP), high incidence of MACE and poor outcome both immediate and 1 year and 6 months follow up. There is high incidence in diabetcis and smokers and hypertensives.

Hypertension was found to be the commonest risk factor followed by smoking, diabetes and dyslipidaemia.

\section{Bibliography}

1. Marc S. Sabatine, Christopher p. cannon. Approach to the patient Christopher $\mathrm{P}$ Cannon. Approach to the patient with chest pain. Braunwald's Heart Disease Tenth Edi;Vol 2;1061.

2. Benjamin M. Scirica, David A. Morrow. ST-Elevation Myocardial Infarction: Pathology, Pathophysiology, and clinical 
features. Braunwald's Heart Disease. Tenth Edi;Vol 2;1088-1089.

3. Robert P.Giuglioano, Christopher P. Cannon, Eugene Braunwald..Non STElevation Acute Cronary Syndrome. Braunwald's Braunwald's Heart Disease. Tenth Edi;Vol2;1155-1158.

4. Elliott M.Antman, Joseph Loscalzo. Ischaemic Hwart Disease. Harrison's Principles of Internal Medicine. $19^{\text {th }}$ Edi;Vol 2;1582.

5. D.E.Newby.N.R. Grubb, A Bradbury. Cardiovascular disease. Davidson's Principles and Practice of Medicine $.22^{\text {nd }}$ Edi.583-600.

6. Gerasimos Siaasos, George Lajaros, Evangelos Oikonomou. The prognostic role of C-Reactive Protein after Myocardial infarction in patient with normal or mildly impaired left ventricle systolic function. International Journal of Cardiology 2016;220:173-175

7. Dawood Sharif, Mahmoud hammoud, Amal Sharif Rasslan. Very vearly CReactive Protein level after Acute Myocardial Infarction Predict early outcome and late prognosis. International Journal of Clinical Medicine 2015,6;547553.

8. Amit Kumar Shrivastava,Harsh Vardhan Singh, Arun raijada. C -Reactive Protein, Inflammation $\mathrm{Nd}$ coronary Heart Disease.The Egyption Heart Journal 2015;26;89-97.

9. Rajni Sharma, Shivkumar Bhairappa, SR Prasad .Clinical Characteristics, Angiographic profile and in Hosspital mortality in Acute Coronary Syndrome patients in South Indian population .Heart India 2014;2:65-69.

10. Raju H. Badiger, V.Dinesha, Arjun Hosalli. Hs-C-Reactive protein as an indicator for prognosis in Acute Myocardial Infarction .Journal of Scientific.
11. The Joint European Society of Cardiology/ American College of Cardiology Committee. Myocardial Infarction redefined - a consensus document of the Joint European Society of Cardiology/ American College of Cardiology Committee for the redefinition of myocardial infarction. J Am Coll Cardiol 2000; 36: 959-69.

12. Relationship of high - Sensitive $C$ reactive protein with cardiovascular risk factors, clinical presentation and angiographic profile in patients with acute coronary syndrome: An Indian perspective: Indian Heart J.2013 May;65(3):359365,doi:10.1016/j.ihj.2013.04.035.

13. Gogna A, Sinha RSK, Gupta B. Creactive protein -marker for atherothrombotic events. J Assoc Physicians India 1999; 47:818-20.

14. Merono PR, Falk E, Palanos IF et al. Macrophage infiltration in acute coronary syndrome. Implication of plaque rupture. Circulation 1994;90:775-778.

15. Gupta S, Leather EW, Caogington D, Mendall M, Kaski JC, Camm AJ Elevated Chlamydia pneumoniae antibodies-cardiovascular events and azithromycin in male survivors of myocardial infarction. Circulation 1997;96:404-407.

16. Libby P, Egan D, Skarlatos, Role of infectious agents in atherosclerosis and restenosis and assessment of the evidence and need for further research. Circulation 1997;96:4095-4103.

17. Niemeta S, Karttunen T, Korhonen T et al. Could helicobacter pylori infection increases the risk of coronary heart disease by modifying serum lipid concentration, Heart 1996;75:573-575.

18. Zhu J, Guyyumi AA, Norman JE et al. Cytomegalovirus in the pathogenesis of atherosclerosis. The role of inflammation as reflected by elevated C-reactive protein 
levels. J Am Coll Cardiol 1999;34:17381743.

19. Fuster V, Badiman Lmmj, Cohen M et al. Insight into the pathogenesis of acute ischaemic syndrome. Circulation 1998; 77:1213-1270.

20. International Journal of advances in medicine Shripad R. Kausadikar, Study of C-reactive protein in patients with acute myocardial infarction attending tertiary care teaching hospital in Saurashtra region of Gujarat, India. October 2009 to September 2010. Kausadikar SR et al. Int J Adv Med. 2016 Nov;3(4):1024-1028.

21. International Journal of Clinical Medicine,2015,6, 547-553Published Online August2015 by Sharif, D., Hammoud, M., Sharif Rasslan, A., Abinader, E. and Odeh,M.(2015) Very Early C-Reactive Protein Levels after Acute Myocardial Infarction Predict Early Outcome and LatePrognosis.

22. Journal of the American College of Cardiology Vol. 58, No. 25, 2011, CReactive Protein and ST-Segment Elevation Myocardial Infarction Discordance* $\mathrm{C}$ by Richard Conti, MD 